기존 간세포암 치료 병변에서 발생한 육종양 담도암 1예: 증례보고 및 문헌고찰

이창건 ${ }^{1} \cdot$ 강경민 $^{1} \cdot$ 이해림 ${ }^{1} \cdot$ 이승원 ${ }^{1} \cdot$ 이희정 ${ }^{2} \cdot$ 한남익 $^{1}$

가톨릭대학교 의과대학 부천성모병원 ${ }^{1}$ 내과, ${ }^{2}$ 병리과

\title{
A Case of Sarcomatoid Cholangiocarcinoma Which Developed at the Site Previously Treated by Transarterial Chemoembolization
}

\author{
Changkun Lee', Kyung Min Kang', Hae Lim Lee', Sung Won Lee', Heejeong Lee ${ }^{2}$, Nam Ik Han \\ Departments of ${ }^{1}$ Internal Medicine and ${ }^{2}$ Pathology, Bucheon St. Mary's Hospital, College of Medicine, The Catholic University of Korea, \\ Bucheon, Korea
}

Received Feb. 3, 2017

Revised Mar. 2, 2017

Accepted Mar. 2, 2017
Intrahepatic sarcomatoid carcinoma is a rare tumor with poor prognosis due to its highly invasive and metastatic nature and difficulty for early detection. The most common form of intrahepatic sarcomatoid carcinoma is the sarcomatoid hepatocellular carcinoma, the development of which is usually associated with previous treatment for hepatocellular carcinoma. In contrast, sarcomatoid cholangiocarcinoma is extremely rare and results from spontaneous sarcomatoid transformation during the development of tumor. Here, we report a case of sarcomatoid cholangiocarcinoma, in a 58-year-old male, which developed at the site of previous treatment for hepatocellular carcinoma. A $9 \times 7 \mathrm{~cm}$ sized tumor which had not been detected in the computed tomography exam 3 months before diagnosis was newly observed. The tumor rapidly progressed and the patient died only 31 days after the diagnosis. (J Liver Cancer 2017;17:100-104)

Keywords: Sarcomatoid carcinoma; Cholangiocarcinoma; Hepatocellular carcinoma

\section{서 론}

육종양 상피암은 체내 여러 기관에서 발생 가능한 것으로 상피성 성분(epithelial component)과 주로 방추형 세포로 이루어진 육종성 성분(sarcomatoid component)이 섞여있는 암종이다. 발생 기전이 아직까지 명확하게 밝혀지지 않았으 며 상피성 육종(carcinosarcoma), 거짓육종(pseudosarcoma) 또는 방추형 세포 상피암(spindle cell carcinoma) 등의 다양 한 이름으로 불리기도 한다. ${ }^{1}$ 간에 발생하는 육종양 상피암

\section{Corresponding author: Hae Lim Lee}

Department of Internal Medicine, Bucheon St. Mary's Hospital, College of Medicine, The Catholic University of Korea, 327 Sosa-ro, Bucheon 14647, Korea Tel. +82-32-340-7670, Fax. +82-32-340-2544 E-mail; leehaelim69@gmail.com
은 훨씬 더 드물며 그중 대부분이 육종양 간세포암으로 알 려져 있고, ${ }^{2,3}$ 특히 육종양 담도암은 전 세계적으로 드물게 보고되고 있다. ${ }^{2,4}$ 저자들은 간세포암을 진단받고 치료 후 완전관해 상태에서, 기존 치료 부위에 급속도로 자란 종괴 가 육종양 담관암으로 증명된 1 예를 경험하여 문헌 고찰과 함께 보고하는 바이다.

\section{증 례}

\section{1. 임상소견}

만성 $\mathrm{B}$ 형간염에 의한 간세포암을 진단받고 치료하였던 환자가 오른쪽 복부 통증을 주소로 내원하였다. 과거력에서 환자는 만성 $\mathrm{B}$ 형간염에 대해 타 병원에서 정기적인 추적관 
찰 중에 복부초음파에서 우연히 발견된 간종괴를 주소로 3 년 전 처음 내원하였다. 당시 복부 전산화단층촬영(computed tomography, CT) 시행 후 간 좌엽 2/3구역 및 간 우엽 5 구 역에 각각 $6 \mathrm{~cm}, 1.5 \mathrm{~cm}$ 크기의 동맥기 조영증강 및 문맥기 조기 배출을 보이는 간세포암을 진단받았다. 내원 4 년 전 환 자는 고혈압, 당뇨를 진단받아 약제를 복용하고 있었으며, 일주일에 3 회, 회당 소주 1 병씩 마신 음주력이 있었다. 새로 진단받은 간세포암에 대해 첫 회 간동맥화학색전술을 시행 받았으며, 동시에 만성 B형간염에 대한 항바이러스 치료 (telbivudine)를 시작하였다. 10개월 후 기존 치료 병변인 5구 역에 $1 \mathrm{~cm}$ 크기의 간세포암이 재발하여 이에 대하여 고주파 열 절제술을 시행하였다. 3 개월 후 8 구역에 새롭게 $1.1 \mathrm{~cm}$ 크기의 간세포암이 발견되어 2 번째 고주파 열 절제술을 시 행하였으나 불완전 치료되어 추가로 2 번째 간동맥화학색전 술을 시행하였다. 10 개월 이후, 1 회 간동맥화학색전술과 1 회 고주파 열 절제술을 시행했던 자리인 간 우엽 5 구역에 2.8 $\mathrm{cm}$ 크기의 간세포암이 재발하여 3 번째 간동맥화학색전술 을 시행하였고, 6 개월 이후 8 구역과 꼬리엽(caudate lobe)인 1 구역에 각각 $1 \mathrm{~cm}$ 정도 크기의 간세포암이 관찰되어 4 번째 간동맥화학색전술을 시행하였다. 3 개월 이후 추적관찰을 위해 외래에서 시행한 복부 전산화 단층촬영에서 재발 소견 은 확인되지 않았다. 다시 3 개월 후, 이번 본원 내원 시 오른 쪽 윗배 통증을 호소하여 시행한 복부 전산화 단층촬영에서 간 우엽 5 구역에, 리피오돌이 침착되어 있는 이전 간동맥화 학색전술 시행 부위를 둘러싸는 $9 \times 7 \mathrm{~cm}$ 크기의 외성장 (exophytic) 종괴가 관찰되었다(Fig. 1A, B). 일반혈액검사에 서 백혈구 $8,720 / \mu \mathrm{L}$, 혈색소 $14.2 \mathrm{~g} / \mathrm{dL}$, 혈소판 $199,000 / \mu \mathrm{L}$ 였 고, 일반화학검사에서 총 단백 $6.5 \mathrm{~g} / \mathrm{dL}$, 알부민 $3.9 \mathrm{~g} / \mathrm{dL}$, as- partate aminotransferase $11 \mathrm{IU} / \mathrm{L}$, alanine aminotransferase 8 $\mathrm{IU} / \mathrm{L}$, 총 빌리루빈 $0.43 \mathrm{~g} / \mathrm{dL}$, alkaline phosphatase $67 \mathrm{IU} / \mathrm{L}$, gamma-glutamyl transpeptidase $23 \mathrm{IU} / \mathrm{L}$ 였다. 혈액응고검사 에서 프로트롬빈 시간은 international normalized ratio (INR) 1.06 (88.5\%)이었으며, 종양표지자검사에서 $\alpha$-fetoprotein (AFP) $3.88 \mathrm{ng} / \mathrm{mL}$, prothrombin induced by vitamin $\mathrm{K}$ absence-II (PIVKA-II) $19 \mathrm{mAU} / \mathrm{mL}$ 였다. 바이러스 간염 표지자 검사에서 HBsAg 양성, HBsAb 음성, $\mathrm{HBeAg}$ 음성, anti-HBe 음성, hepatitis B virus (HBV) DNA $34 \mathrm{IU} / \mathrm{mL}$ 미만이었고, anti-hepatitis C virus $(\mathrm{HCV})$ 음성이었다.

\section{2. 영상소견}

진단을 위하여 추가로 시행한 복부 자기공명영상(magnetic resonance imaging, MRI)에서도 마찬가지로 간 우엽 5 구역에 $9 \times 7 \mathrm{~cm}$ 의 외성장 종괴가 확인되었으며 불규칙한 형태로, 내부의 동맥기 조영증강이 명확하지 않으면서 변연 부는 지연 조영증강 되어 보였다(Fig. 1C). 이외에도 간 전체 엽에서 다발성의 $1 \mathrm{~cm}$ 미만의 작은 결절들이 관찰되었으며, 이 병변들은 동맥기에 변연부가 조영증강 되며 간담도기 (hepatobiliary phase)에서 중앙부로 차 들어가는 듯한 양상 을 보여 전이성 병변으로 판단되었다.

\section{3. 진단 및 치료경과}

간내 종괴가 간 변연부에 위치하고 있었으며, 자라는 속 도에 의해 파열 가능성이 높다고 판단하여 개복술을 시행 하기로 하고 양전자 방출 컴퓨터 단층 촬영 (positron emis-
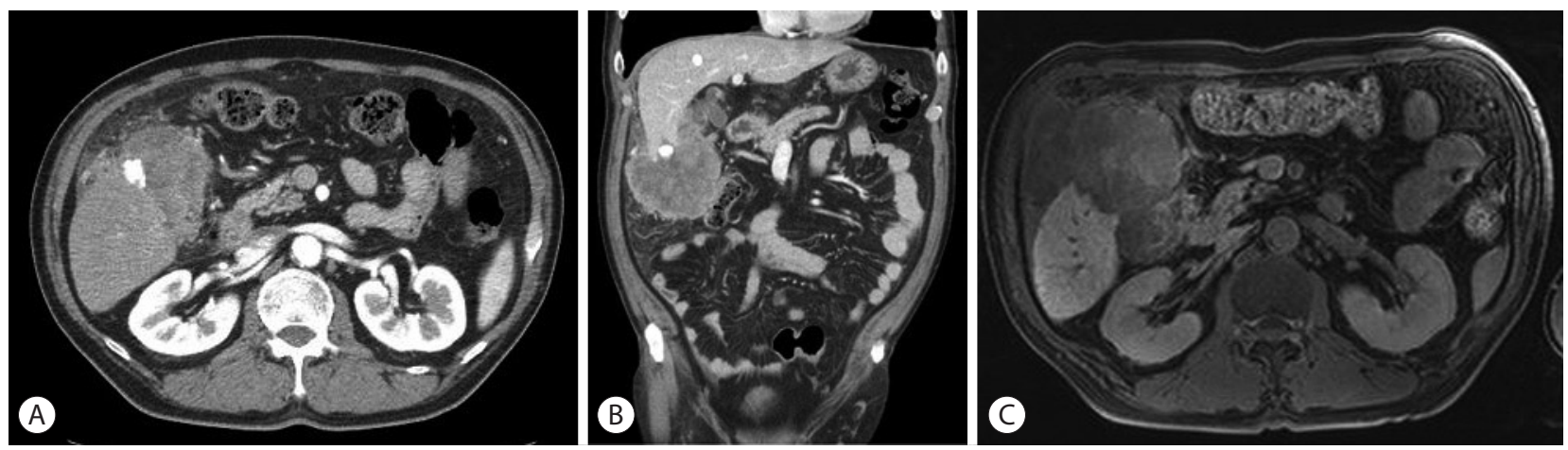

Figure 1. Abdominal CT and MRI findings. CT scan showed a $9 \mathrm{~cm}$ sized heterogenous low density mass surrounding lipiodol laden lesion on the liver segment 5 (A, B). MRI scan also showed an exophytic mass in T1 weighted image (portal phase) (C). CT, computed tomography; MRI, magnetic resonance imaging. 
sion tomography-computed tomography, PET-CT)을 시행 하였고, 간내 종괴 외에 간주변부와 간주변부의 장간막과 대망(omentum)으로의 악성 종양 침범 소견이 확인되었다 (Fig. 2). 개복 결과 외성장 종괴를 대망이 감싸는 형태였으 며, 대망에 전이된 병변으로 의심되는 다발성 결절들이 확 인되어 수술은 불가능하다고 판단한 후, 결절에 대하여 냉 동 생검만 시행하고 수술을 마쳤다. 조직 검사 결과 hematoxylin 및 eosin $(\mathrm{H} \& \mathrm{E})$ 염색에서 간세포암을 시사하는 소 주(trabecular) 패턴 또는 둥지(nesting) 패턴 소견이 보이지 않았고, 비정형, 다형성의 방추형 또는 타원형의 세포가 특 별한 구조 없이 흩어져 있는 양상을 보였다(Fig. 3). 면역조 직화학염색에서는 hepatocyte, AFP에 음성이었고, vimentin 양성, pancytokeratin (AE1/AE3) 양성, cytokeratin (CK) 7과 19에 양성을 보여 육종성 선암, 그중에서도 육종양 담관암 의 복막 전이로 진단하였다(Fig. 4). 이후 항암치료를 고려

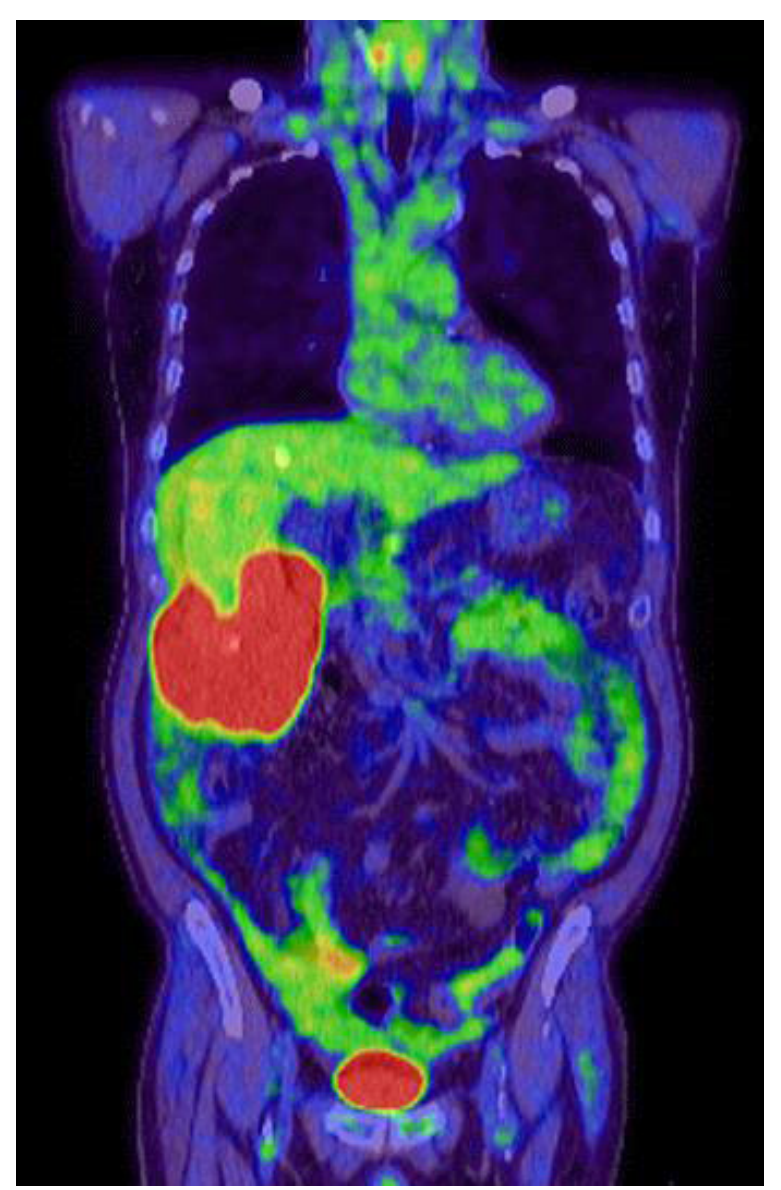

Figure 2. PET-CT finding. PET-CT showed a hypermetabolic lesion (standard uptake value [SUV] 17.45) in liver segment 5 and local invasion to perihepatic, subhepatic, mesenteric and omentum. PET$\mathrm{CT}$, positron emission tomography-computed tomography.
하였으나, 종양 진행으로 인한 전신 수행도가 Eastern Cooperative Oncology Group 3-4로 점차 악화되어 이에 대 한 보존적 치료 중 입원 31 병일째 사망하였다.

\section{고 찰}

간에 발생하는 육종양 상피암은 매우 드문 것으로 알려져 있으며 그중 많은 경우가 기존의 간세포암이나 담도암에서 의 육종성 변화와 관련하여 보고되고 있다. 부검 결과로 보 고된 것에 따르면 간세포암의 육종성 변화는 3.9-9.4\% 정도 로 대부분 간동맥화학색전술, 고주파 열 소작술 또는 항암 화학요법을 받은 후 등 종양세포의 이차적인 변화와 관련 되어 보고된다. 하지만 담도암에서는 $4.5 \%$ 정도로 항암 치 료와의 연관성에 대해서 보고되고 있지 않아, 종양 발생 중 자연 경과로 육종성 변화를 일으켰을 것이라 여겨지고 있
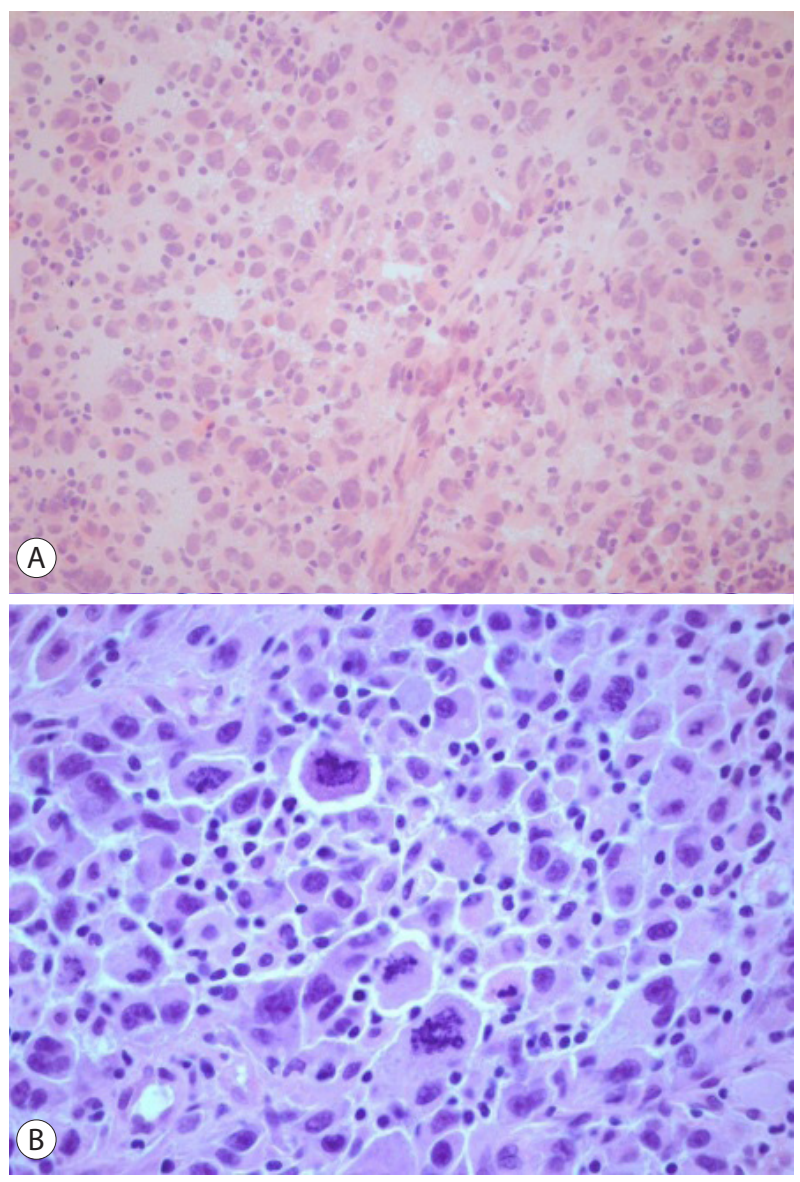

Figure 3. Microscopic findings from a resected specimen. The tumor was consisted with highly pleomorphic or atypical cells without specific structure (A: Hematoxylin \& Eosin, $\times 200$; B: Hematoxylin \& Eosin, $\times 400)$. 

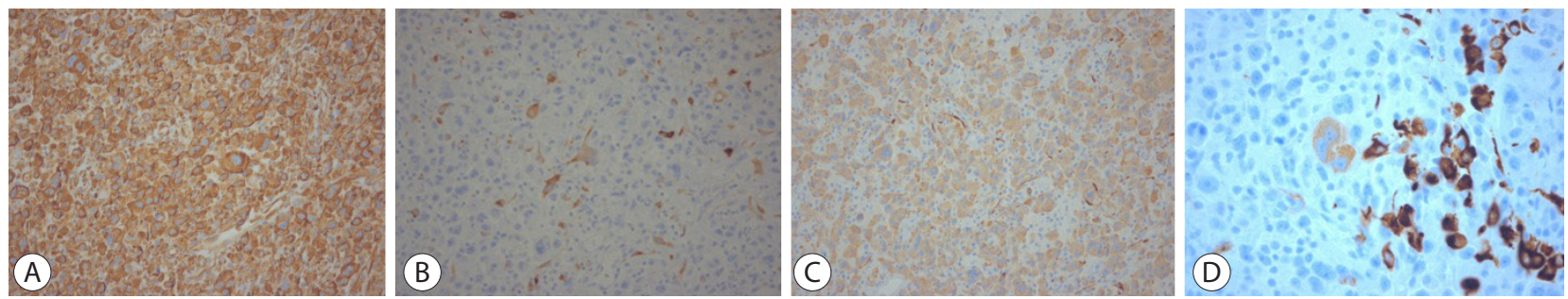

Figure 4. Immunohistochemical findings. The tumor cells were positive for vimentin (A: $\times 200)$, pancytokeratin $(A E 1 / A E 3)(B: \times 200)$, cytokeratin 7 (C: $\times 200)$ and cytokeratin $19(\mathrm{D}: \times 400)$.

다. ${ }^{4-7}$ 간내 원발성으로 발생하는 육종양 상피암은 전 세계 적으로도 드물게 보고되고 있다. ${ }^{8}$ 특히 본 증례는 기존 간암 으로 진단되어 치료받은 후 완전관해 상태에서, 여러 차례 치료받은 부위에 발생한 빠르게 증식하는 종양이 조직 검사 결과 육종성 담도암으로 진단된 드문 예라고 할 수 있다.

육종양 상피암의 발생기전은 아직까지 잘 알려져 있지 않 으나, 상피-간엽전환(epithelial-mesenchymal transition, $\mathrm{EMT}$ )으로 육종성 변화를 설명하기도 한다. 육종양 상피암 은 보통 다형성(pleomorphic)의 방추형 세포로 이루어져 있 는데, 전형적인 형태는 적어도 부분적으로 상피성 성분을 가지고 있으며 육종성 세포가 $\mathrm{CK}$ 에 양성을 보이기도 한다. 이러한 것들은 육종양 상피암이 상피암으로부터 육종성 변 화를 일으켜 발생되었다고 설명하는 것의 근거가 된다. ${ }^{9}$ 상 피-간엽전환은 상피세포에서 상피성 표현형이 이동성, 침 습성 특성을 갖는 등의 여러 생화학적 변화를 겪으며 중간 엽 표현형으로 변화하는 과정을 이야기한다. ${ }^{910}$ 이외에도 다 양한 방향으로 분화 가능한 중립의 예비세포(multipotent reserve cell)에서 암종 및 육종으로 분화했다고 설명하기도 한다. ${ }^{4,11}$

육종양 담도암은 다른 간종양처럼 무증상 또는 복통, 체 중감소, 피로나 구토 증세로 나타날 수 있으나 특히 발열이 나 복통이 좀 더 특이적인 증상이다. ${ }^{2,12}$ 본 증례의 환자 또한 복통을 주소로 내원하였으며, 검사를 위해 시행한 복부 전 산화 단층 촬영에서 간세포암에 대한 추적진료를 위해 시행 한 3 개월 전의 영상에서는 확인되지 않았던 $9 \times 7 \mathrm{~cm}$ 크기의 외성장 종괴가 확인되었다. 영상 검사 소견에서는 종괴 내 부로 동맥기 조영증강이 명확하지 않으면서 괴사를 동반하 고, 경계부는 지연 조영증강 되는 소견을 보였는데, 이는 기 존에 보고된 육종양 담도암의 특징적인 소견과 일치한 다. ${ }^{13,14}$

최종진단은 조직학적 소견과 면역조직화학 염색을 통해 이루어진다. 조직학적으로 육종양 담도암은 다양한 비율로
육종성 상피암과 담도암의 성분이 섞여서 존재하며, ${ }^{2}$ 이 두 가지 사이의 중간 형태 또한 발견할 수 있다. ${ }^{15}$ 담도암 성분 은 대부분 분화도가 중간 또는 매우 나쁜 선암세포로 이루 어지고, 육종성 성분은 방추형 세포와 다형성 세포가 혼합 된 형태로 존재한다. ${ }^{2}$ 방추형 세포의 핵은 타원형 또는 길게 생겼고 핵소체가 크고 뚜렷하다. 세포들은 다발을 이루어 교차되거나 소용돌이 패턴을 보이기도 하고, 유사분열(mitotic figures) 또한 종종 관찰된다. ${ }^{16}$ 면역조직화학염색에서 는 상피세포 표지자인 CK, epithelial membrane antigen (EMA), 간엽세포 표지자인 vimentin이 양성으로 이에 대한 검사가 도움이 된다. 육종양 상피암의 진단에는 간내 발생 하는 다른 육종암과의 감별도 중요한데, 이런 종양들은 대 부분 $\mathrm{CK}$ 나 $\mathrm{EMA}$ 에 음성으로 나타난다. ${ }^{16}$ 본 증례의 조직에 서는 비정형, 다형성의 방추형, 타원형 세포들이 특별한 구 조를 보이지 않으면서 흩어져 있었고, 면역조직화학염색에 서 vimentin 양성, pancytokeratin (AE1/AE3) 양성, CK 7, CK 19 에 양성을 보여 육종양 담관암으로 진단되었다. 기존 보 고들에서 육종양 담도암과 이전 항암 치료와의 관련성은 찾을 수 없었으나, 본 증례에서는 간세포암에 대해 간동맥 화학색전술 2 회, 고주파열소작술 1 회를 시행했던 자리에서 발생한 종양이었다. 조직검사 결과 $\mathrm{H \& E}$ 염색에서 간세포 암을 시사하는 세포 배열인 소주 패턴이나 둥지 패턴을 찾 을 수 없었으며, 면역조직화학염색에서도 AFP와 hepatocyte 에 음성이나, CK 7, CK 19에 양성으로 육종양 담도암으로 판단되었다.

육종양 담도암은 드문 빈도로 아직까지 정립된 치료 방법 이 없으나 현재까지 보고된 증례들을 보면 가능한 경우 수 술을 먼저 많이 시도하고 있다. ${ }^{24}$ Kaibori 등은 육종양 담도 암으로 진단받은 16 명의 환자를 대상으로 수술을 시행한 경우와 그렇지 않은 경우의 생존율을 비교하였고, 결과는 수술을 시행한 경우가 생존율이 유의하게 높았다. 수술 후 보조항암화학요법으로 젬시타빈(gemcitabine), 시스플라틴 
(cisplatin) 병용요법을 시행하여 생존이득을 경험하였다는 사례 또한 있었다. 그러나 종양이 자라는 속도도 빠르며, 치료 후 높은 재발률, 진단 시 혈관이나 림프절, 타 장기 전 이도 같이 많이 발견되어 예후는 매우 나쁜 것으로 알려져 있다. ${ }^{2,4}$ 육종양 상피암의 중간 생존 기간은 9.6개월, 3 년 생 존율은 $17 \%$ 정도로 보고된다. ${ }^{8}$ 본 증례의 환자도 입원 시 간 내 종괴외 혈액 검사 등의 특이 소견은 없었으나, 입원 후 31 병일만에 급격하게 전신상태가 악화되어 사망하였다.

육종양 담도암은 원래 빠른 진행으로 예후가 불량한 것 으로 알려져 있으나, 본 증례 또한 3개월 사이 새로 발생한 종양이 진단 당시 타 기관에 이미 전이된 상태로, 이후의 경 과 또한 빠르게 악화되어 진행 정도가 급격하였다고 할 수 있다. 육종양 담도암에 대한 이전의 보고들이 대부분 기존 의 치료와 관련이 없었으나, 본 증례는 간세포암에 대해 여 러 차례 치료를 시행한 부위에서 발생한 종양이었다는 점에 서도 매우 드문 사례라고 할 수 있다. 본 증례의 보고를 통해 드물게 발생하는 육종성 담도암에 대한 이해도를 더 높일 수 있을 것이다.

\section{Conflicts of Interest}

The authors have no conflicts to disclose.

\section{REFERENCES}

1. Lu J, Zhang J, Xiong XZ, Li FY, Ye H, Cheng Y, et al. Primary hepatic sarcomatoid carcinoma: clinical features and prognosis of 28 resected cases. J Cancer Res Clin Oncol 2014;140:1027-1035.

2. Kaibori M, Kawaguchi Y, Yokoigawa N, Yanagida H, Takai S, Kwon $\mathrm{AH}$, et al. Intrahepatic sarcomatoid cholangiocarcinoma. J Gastroenterol 2003;38:1097-1101.

3. Yamaguchi R, Nakashima O, Yano H, Kutami R, Kusaba A, Kojiro M. Hepatocellular carcinoma with sarcomatous change. Oncol Rep 1997;4:525-529.

4. Lee DH, Han KH, Ahn SY, Kim SS, Shin HS, Bang KB, et al. Sarcomatoid intrahepatic cholangiocarcinoma: a rare case of primary liver cancer. J Liver Cancer 2016;16:139-144.

5. Giunchi F, Vasuri F, Baldin P, Rosini F, Corti B, D'Errico-Grigioni A. Primary liver sarcomatous carcinoma: report of two cases and review of the literature. Pathol Res Pract 2013;209:249-254.

6. Chin S, Kim Z. Sarcomatoid combined hepatocellular-cholangiocarcinoma: a case report and review of literature. Int J Clin Exp Pathol 2014;7:8290-8294. eCollection 2014.

7. Malhotra S, Wood J, Mansy T, Singh R, Zaitoun A, Madhusudan S. Intrahepatic sarcomatoid cholangiocarcinoma. J Oncol 2010;2010:701476.

8. Wang QB, Cui BK, Weng JM, Wu QL, Qiu JL, Lin XJ. Clinicopathological characteristics and outcome of primary sarcomatoid carcinoma and carcinosarcoma of the liver. J Gastrointest Surg 2012;16:17151726.

9. Sung CO, Choi H, Lee KW, Kim SH. Sarcomatoid carcinoma represents a complete phenotype with various pathways of epithelial mesenchymal transition. J Clin Pathol 2013;66:601-606.

10. Kim HM, Kim H, Park YN. Sarcomatoid cholangiocarcinoma with osteoclast-like giant cells associated with hepatolithiasis: a case report. Clin Mol Hepatol 2015;21:309-313.

11. Kim WS, Kim TH, Hwang JJ, Kim HJ, Jung WT, Lee OJ, et al. A case of intrahepatic sarcomatoid cholangiocarcinoma with rhabdoid transformation. Korean J Med 2011;80:453-457.

12. Eriguchi N, Aoyagi S, Hara M, Okuda K, Fukuda S, Tamae T, et al. Malignant sarcomatoid tumor of the liver: report of a case. Surg Today 2001;31:170-173.

13. Koo HR, Park MS, Kim MJ, Lim JS, Yu JS, Jin H, et al. Radiological and clinical features of sarcomatoid hepatocellular carcinoma in 11 cases. J Comput Assist Tomogr 2008:32:745-749.

14. Yoshida N, Midorikawa Y, Kajiwara T, Yoshida N, Nakayama H, Sugitani $\mathrm{M}$, et al. Hepatocellular carcinoma with sarcomatoid change without anticancer therapies. Case Rep Gastroenterol 2013;7:169-174.

15. Nakajima T, Tajima Y, Sugano I, Nagao K, Kondo Y, Wada K. Intrahepatic cholangiocarcinoma with sarcomatous change. Clinicopathologic and immunohistochemical evaluation of seven cases. Cancer 1993;72:1872-1877.

16. Leng Q, Xiang XI, Tang Y, Yang Y, Qiu LI. Primary hepatic sarcomatoid carcinoma: a case report. Exp Ther Med 2015;10:1145-1148. 